\title{
Synthesis, characterization and in vitro Antimicrobial activity of $\mathrm{Cu}$ (II) and Ni (II) complexes of Azo-carboxylate derived from substituted Anilines
}

\author{
Keisham Surjit Singh ${ }^{1}$, Manojit Roy ${ }^{1}$, SanasamSachika Devi ${ }^{1}$, \\ W. Radhapiyari Devi². \\ ${ }^{1}$ (Department of Chemistry, National Institute of Technology Agartala, Jirania, Tripura West-799055,India) \\ ${ }^{2}$ (Institute of Bioresources and Sustainable Development, IBSD, Takyelpat, Imphal, Manipur-795001, India)
}

\begin{abstract}
Four $\mathrm{Cu}(\mathrm{II})$ and two Ni(II) complexes of azo carboxylate ligands were synthesized and characterized by conductivity, UV-visible and Infrared spectroscopy. The comparison of IR spectra of uncoordinated ligands and their metal complexes indicated that ligands were coordinated to the metal through carboxylic oxygen atom in bidented fashion. The electronic spectral data suggested square planner geometry of the complexes. The conductivity study of the complexes indicated $\mathrm{Cu}(\mathrm{II})$ complexes are nonelectrolyte while Ni(II) complexes are electrolyte in nature. All the complexes were tested for their in vitro antibacterial and antifungal activity against different microbes and compared with standard drugs, Amphotericin-B and Ciprofloxacin. It was observed that $\mathrm{Ni}(I I)$ complexes are more effective than the corresponding $\mathrm{Cu}(\mathrm{II})$ complexes. $\mathrm{Cu}(\mathrm{II})$ complexes were found to be inactive against the tested fungal species but they show moderate activity against the tested bacterial species. One of the Ni(II) complex was found to be active in both fungal and bacterial species and also found to be more effective than the other complexes.
\end{abstract}

Keywords: Azo-carboxylates, antimicrobial activity,conductivity, IR spectroscopy.

\section{Introduction}

Coordination chemistry of $\mathrm{Cu}(\mathrm{II})$ and $\mathrm{Ni}(\mathrm{II})$ complexes of chelating ligands has been growing interest for their structures, spectral, and redox properties [1]. Large number of $\mathrm{Cu}(\mathrm{II})$ and $\mathrm{Ni}(\mathrm{II})$ complexes with different chelating ligands were reported and such complexes have shown significant antibacterial, antifungal, anticancer, antiviral and herbicidal properties [2-7] and such activities were found to be enhanced on coordination/chelation. Chelating ligands containing $\mathrm{N}, \mathrm{S}$ and $\mathrm{O}$ donors show broad biological activity and are of special interest because of their variety of ways in which they are bonded to metal ions. It has also been reported that coordination of metal ions to biologically active compounds may also enhance their activities [7-9].These compounds are not only good candidates as antimicrobial agents, but may also be considered promising addition of new class of compounds as the metal based drugs[10].Further, synthesis, characterization and in vitro antibacterial and antifungal activity of large number of schiff base transition metal complexes were reported in the literature[1-7]. However, synthesis, characterization and biological property of transition metal complexes of azo-carboxylate have not been studied in details as compared to schiff base transition metal complexes. In view of these, we have synthesized and characterized some new $\mathrm{Cu}(\mathrm{II})$ and $\mathrm{Ni}(\mathrm{II})$ complexes of azo carboxylate ligand and evaluated their in vitro antimicrobial activity.

In our present study, ligandsL $\mathrm{L}_{1}$ andL $_{2}(\mathbf{F i g}$.1)were obtained by the diazotization of para-toluidine and sulfanilamide and then coupled with salicylic acid. Corresponding metal(II) complexes of the type $[\mathrm{Cu}(\mathrm{II})(\mathrm{L})(\mathrm{ac})]$ (where $\mathrm{L}=\mathrm{L}_{1}=\mathrm{L}_{2}$ ) were obtained by the stoichiometric reaction ratio of $\mathrm{M}: \mathrm{L}$ as $(1: 1)$.
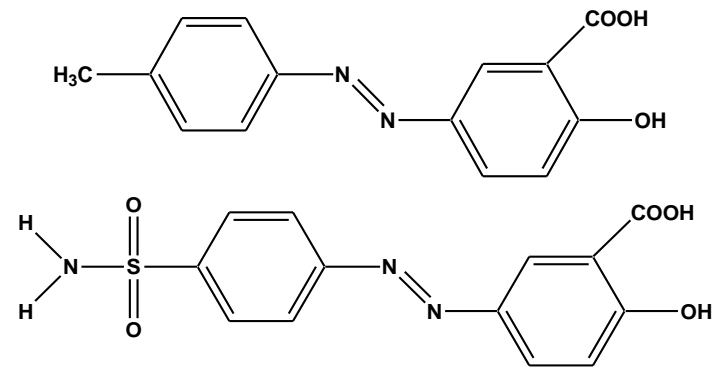

Fig.-1: Proposed structures of the ligands $\left(\mathrm{L}_{1}\right) \&\left(\mathrm{~L}_{2}\right)$.

On the other hand, complexes of the type $\left[\mathrm{M}(\mathrm{II})(\mathrm{L})_{2}\right][$ where $\mathrm{M}(\mathrm{II})=\mathrm{Cu}(\mathrm{II})$ and $\mathrm{Ni}(\mathrm{II})]$ were synthesized by the stoichiometric ratio of $\mathrm{M}: \mathrm{L}$ as $(1: 2)$. All the compounds were characterized by conductivity, UV andIR 
spectroscopy.The complexes were screened for their in vitro antibacterial and antifungal activity against different bacteria such as S. Paratyphi,P. Aeruginosa, P. Mirabilis, K. Pneumoniae, E. coli and different fungi such as A. Flavus, A. Niger, C. Albicans, A. Fumigatus and C. Krusei.The antimicrobial activity of the complexes were compared with the standard drugs, Amphotericin-B and Ciprofloxacin.

\subsection{Method and materials}

\section{Experimental}

Copper(II)acetate mono hydrate and Nickel(II)sulphate hepta hydrate were used as metal(II) salts. AR grade solvents were used in all the reactions and dried using standard procedures. Electronic spectra of the complexes in DMSO $\left(10^{-3} \mathrm{M}\right)$ were recorded in UV-1800 Shimadzu spectrophotometer. IR spectra in the range of $4000-400 \mathrm{~cm}^{-1}$ were obtained on Shimadzu FT-IR-8400S spectrophotometer using $\mathrm{KBr}$ discs. Proton NMR for $\mathrm{L}_{1}$ and $\mathrm{L}_{2}$ was recorded on a Bruker AMX 300 spectrophotometer in DMSOd $_{6}$ and measured at 300.13 MHz.

\subsection{Synthesis of ligands}

2.2.1 5-[(E)-2-(4-Methylphenyl)-1-diazenyl)]-2-hydroxybenzoic acid $\left(\mathrm{L}_{1}\right)$

The ligand was prepared following the reported procedure [11]. Yield(\%):52,M.p:- 219-220 ${ }^{\circ} \mathrm{C}$, Molecular formula: $\mathrm{C}_{14} \mathrm{H}_{12} \mathrm{~N}_{2} \mathrm{O}_{3} .{ }^{1} \mathrm{H}-\mathrm{NMR}$ (DMSO- $d_{6} / 300 \mathrm{MHz}$ ); $\delta_{\mathrm{H}:} 2.41$ [s, $\left.3 \mathrm{H}, \mathrm{CH}_{3}\right], 7.06-8.48$ [7H,Ar-H] ppm.Signals for the phenol and carboxylic acid were exchanged due to presence of water in the solvent.

\subsubsection{Synthesis of 5-[(E)-2-(4-sulphonamidophenyl)-1-diazenyl)]-2-hydroxybenzoic acid $\left(\mathrm{L}_{2}\right)$}

Sulphanilamide (5 gm, $29.03 \mathrm{mmol}$ ) was mixed with $12 \mathrm{ml}$. conc. $\mathrm{HCl}$ and $36 \mathrm{ml} \mathrm{H}_{2} \mathrm{O}$ and digested in water bath for about 45 minutes. The aniline hydrochloride was cooled to $0-5^{\circ} \mathrm{C}$ and diazotized with ice cold $20 \mathrm{~mL}$ aq. $\mathrm{NaNO}_{2}$ solution $(2 \mathrm{gm}, 29.01 \mathrm{mmol})$. A cold solution of salicylic acid (4 gm, $\left.29.03 \mathrm{mmol}\right)$, previously dissolved in $10 \% \mathrm{NaOH}$ solution $(50 \mathrm{ml})$ was then added to the cold diazonium salt solution with vigorous stirring. An orange colour developed almost immediately and the stirring was continued for 1 hour. The reaction mixture was kept overnight in a refrigerator, followed by $3 \mathrm{~h}$ at room temperature and then acidified with dilute acetic acid whereupon an orange precipitation separated out. The precipitated was filtered, washed several times with water to remove excess acetic acid \& water soluble minerals and then dried in air. Yield:56, M.p: 208-210 ${ }^{\circ} \mathrm{C}$,Molecular formula: $\mathrm{C}_{13} \mathrm{H}_{11} \mathrm{O}_{5} \mathrm{~N}_{3} \mathrm{~S} .{ }^{1} \mathrm{H}-\mathrm{NMR}$ (DMSO-d6/300 MHz); $\delta \mathrm{H}: 7.51[2 \mathrm{H}$, $\left.\mathrm{SO}_{2} \mathrm{NH}_{2}\right], 7.16-8.37[7 \mathrm{H}, \mathrm{Ar}-\mathrm{H}] \mathrm{ppm}$. Signals for the phenol and carboxylic acid were exchanged due to presence of water in the solvent.

\subsection{Synthesis of metal(II)complexes}

2.3.1Synthesis of $\left[\mathrm{Cu}(\mathrm{II}) \mathrm{L}_{1}(\mathrm{ac})\right]$

To methanolic solution of $\mathrm{L}_{1}(0.5 \mathrm{~g}, 1.95 \mathrm{mmol})$, methanolic solution of triethylamine $(0.195 \mathrm{~g}, 1.95$ mmol.) was added drop wise with continuous stirring. An aqueous solution of copper(II) acetate $(0.38 \mathrm{~g}, 1.95$ mmol) was added to the above stirred solution.The reaction mixture was refluxed for $3 \mathrm{~h}$ and filtered. The residue was washed with water, methanol and diethyl ether and dried in vacuum desiccators which afforded the desired product.Yield(\%): 48, M.p:> 275, Molecular formula: $\mathrm{C}_{16} \mathrm{O}_{6} \mathrm{~N}_{2} \mathrm{H}_{16} \mathrm{Cu}$.

\subsubsection{Synthesis of $\left[\mathrm{Cu}(\mathrm{II})\left(\mathrm{L}_{1}\right)_{2}\right]$}

To $(0.5 \mathrm{gm}, 1.95 \mathrm{mmol})$ methanolic solution of $\mathrm{L}_{2}$, methanolic solution of triethylamine $(0.19 \mathrm{~g}$, $1.95 \mathrm{mmol})$ was added dropwise with continuous stirring. To this solution, an aq. solution of $\mathrm{Cu}\left(\mathrm{CH}_{3} \mathrm{COO}\right)_{2} \cdot \mathrm{H}_{2} \mathrm{O}$ $(0.19 \mathrm{gm}, 0.976 \mathrm{mmol})$ was added and stirring was continued for half an hour. The reaction mixture was then refluxed for $3 \mathrm{~h}$ and filtered. The residue was washed with water, methanol and diethyl and dried in air.Yield (\%): 39,M.p:> 275, Molecular formula: $\mathrm{C}_{28} \mathrm{O}_{6} \mathrm{~N}_{4} \mathrm{H}_{22} \mathrm{Cu}$.

\subsubsection{Synthesis of $\left[\mathrm{Cu}(\mathrm{II}) \mathrm{L}_{2}(\mathrm{ac})\right]$}

To $(0.5 \mathrm{gm}, 1.557 \mathrm{mmol})$ methanolic solution of $\mathrm{L}_{2}$, triethylamine $(0.157 \mathrm{~g}, 1.557 \mathrm{mmol})$ in methanol $(10 \mathrm{~mL})$ was added dropwise with continuous stirring. To this solution, an aqueous solution of $\mathrm{Cu}\left(\mathrm{CH}_{3} \mathrm{COO}\right)_{2} \cdot \mathrm{H}_{2} \mathrm{O}(0.310 \mathrm{gm}, 1.557 \mathrm{mmol})$ was added dropwise and stirring was continued for half an hour. The reaction mixture was then refluxed for $3 \mathrm{~h}$ and filtered.The filtrate was concentrated and was leftovernight at room temperature. The solid mass was filtered, washed repeatedly with water. The product so obtained was washed with methanol, diethyl ether and dried in vacuum.Yield (\%):47, M.p:> 275,Molecular formula: $\mathrm{C}_{15} \mathrm{O}_{7} \mathrm{~N}_{3} \mathrm{H}_{13} \mathrm{SCu}$. 


\subsubsection{Synthesis of $\left[\mathrm{Cu}(\mathrm{II})\left(\mathrm{L}_{2}\right)_{2}\right]$}

To $(0.5 \mathrm{gm}, 1.557 \mathrm{mmol})$ methanolic solution of $\mathrm{L}_{2}$, triethylamine $(0.157 \mathrm{gm}, 1.557 \mathrm{mmol})$ in methanol was added dropwise with continuous stirring. An aq. solution of $\mathrm{Cu}\left(\mathrm{CH}_{3} \mathrm{COO}\right)_{2} \cdot \mathrm{H}_{2} \mathrm{O}(0.155 \mathrm{gm}, 0.778 \mathrm{mmol})$ was added drop wise to the above solution. The reaction mixture was refluxed for $3 \mathrm{~h}$. and filtered. The filtrate was concentrated and was left overnight at room temperature.The solid mass was filtered, washed repeatedly with water.The product so obtained was washed with methanol, diethyl ether and dried in vacuum .Yield (\%) :52,M.p:> 275, Molecular formula: $\mathrm{C}_{26} \mathrm{O}_{10} \mathrm{~N}_{6} \mathrm{H}_{18} \mathrm{~S}_{2} \mathrm{Cu}$.

\subsubsection{Synthesis of $\left[\mathrm{Ni}(\mathrm{II})\left(\mathrm{L}_{1}\right)_{2}\right] . \mathrm{SO}_{4}$}

To $(0.5 \mathrm{gm}, 1.95 \mathrm{mmol})$ methanolic solution of $\mathrm{L}_{1}$, triethylamine $(0.197 \mathrm{~g}, 1.95 \mathrm{mmol})$ in $10 \mathrm{~mL}$ methanol was added dropwise with continuous stirring. A solution of aq. $\mathrm{NiSO}_{4} .7 \mathrm{H}_{2} \mathrm{O}(0.267 \mathrm{gm}, 0.97 \mathrm{mmol})$ was added to the above solution. The reaction mixture was then refluxed for $3 \mathrm{~h}$. It was then filtered, and the residue was washed with water, methanol and finally by diethyl ether \& dried in vacuum.Yield (\%):46,M.p:> 275, Molecular formula: $\mathrm{C}_{28} \mathrm{O}_{7} \mathrm{~N}_{4} \mathrm{H}_{24} \mathrm{Ni}$.

\subsubsection{Synthesis of $\left[\mathrm{Ni}(\mathrm{II})\left(\mathrm{L}_{2}\right)_{2}\right] . \mathrm{SO}_{4}$}

To $(0.5 \mathrm{gm}, 1.557 \mathrm{mmol})$ methanolic solution of $\mathrm{L}_{2}$, solution of triethylamine $(0.157 \mathrm{~g}, 1.557 \mathrm{mmol})$ in $10 \mathrm{~mL}$ methanol was added dropwise with continuous stirring. To this solution, an aq. solution of $\mathrm{NiSO}_{4} \cdot 7 \mathrm{H}_{2} \mathrm{O}$ $(0.106 \mathrm{gm}, 0.778 \mathrm{mmol})$ was added dropwise.The reaction mixture was refluxed for $3 \mathrm{~h}$. The reaction mixture was then filtered and the filtrate was concentrated whereupon a solid precipitation was obtained. The solid precipitation was filtered and washed with water, methanol and diethyl ether and dried in vacuum .Yield (\%):37,M.p:176-78,Molecular formula: $\mathrm{C}_{26} \mathrm{O}_{12} \mathrm{~N}_{6} \mathrm{H}_{22} \mathrm{~S}_{2} \mathrm{Ni}$.

\subsection{Antimicrobial activity}

Material and Method

The antimicrobial activity was assessed by agar well diffusion method using $20 \mathrm{ml}$ of sterile Nutrient Agar (NA) (Hi-Media) and Potato-Dextrose Agar (PDA) (Hi-Media) and Sabouraud Dextrose Agar SDA (HiMedia) for testing the bacterial and filamentous fungal and yeast activity [12]. The test cultures were swabbed on the top of the solidified media and allowed to dry for $10 \mathrm{~min}$. sterile $6 \mathrm{~mm}$ diameter cork borer were pierced in the agar at equidistant. Each compound was diluted in $5 \mathrm{mg} / \mathrm{ml}$. The dilution of the compounds concentration were deposited $20 \mu \mathrm{l}$ on the inoculated well and left for $10 \mathrm{~min}$ at room temperature for the compound diffusion. Negative control was prepared using DMSO. Amphotericin-B (Hi-Media) for fungi and yeast and Ciprofloxacin (Hi-Media) for bacteria were served as positive control. The plates were inoculated with bacteria and were incubated at $37^{\circ} \mathrm{C}$ for $24 \mathrm{hr}$, and for fungal cultures, at $30^{\circ} \mathrm{C}$ for $24-48 \mathrm{hr}$. The experiment was repeated thrice and the average results were recorded. The antimicrobial activity was determined by measuring the diameter of the inhibition zone $(\mathrm{mm})$ around the well.

\subsection{Synthesis}

\section{Results And Discussion}

Ligand $\mathrm{L}_{2}$ was prepared by diazo-coupling of sulfanilamide with salicylic acid under alkaline cold condition while $\mathrm{L}_{1}$ was prepared following the reported procedure[11]. Four new $\mathrm{Cu}$ (II)and two $\mathrm{Ni}(\mathrm{II})$ complexes were synthesised by stirring and then refluxing the methanolic solution of the ligands with corresponding metal(II) salts using 1:1 and 2:1 molar ratio of ligands and metal salts. All the complexes are soluble DMSO and DMF. The analytical data, colour, percentage yields, melting points of the complexes are presented in Table 1 and reaction for the synthesis of azo ligands and metal complexes are given in scheme 1.

\subsection{Spectroscopic characterization \\ 3.2.1Electronic spectra}

Electronic absorption spectra of the metal(II) complexes were recorded in $10^{-4} \mathrm{~mol} \mathrm{~L}^{-1}$ solutions of each complex in DMSO from 200 to $1100 \mathrm{~nm}$ at room temperature and their results are presented in Table 2.Electronic spectra of the $\mathrm{Cu}(\mathrm{II})$ complexes in DMSO show a broad band at $24038-25381 \mathrm{~cm}^{-1}$. This broad band may be assigned to the ${ }^{2} \mathrm{~B}_{1 \mathrm{~g}} \rightarrow{ }^{2} \mathrm{E}_{\mathrm{g}}$ transition of four coordinate, square- planar geometry [13,14]. Electronic spectra of the $\mathrm{Ni}(\mathrm{II})$ complexes show bands at $25126-25189 \mathrm{~cm}^{-1}$ which are assignable to ${ }^{1} \mathrm{~A}_{1 \mathrm{~g}}$ $\rightarrow{ }^{1} \mathrm{E}_{\mathrm{g}}$ transition in a square - planar geometry[14,15]. At higher energy, intense absorption was observed in the range 31646- $40984 \mathrm{~cm}^{-1}$ which are likely due to charge transfer or intra ligand transition[16].

\subsubsection{Infrared Spectra}

The IR spectra of the ligands and the complexes 1-6were recorded and IR data are given in Table 3 while their IR spectra are shownin Fig. 2-6. The IR bands observed at $1655-1665 \mathrm{~cm}^{-1}$ due to $v(\mathrm{OCO})$ 
asymmetric stretching in $\mathrm{L}_{1}$ and $\mathrm{L}_{2}$ were reduced to $1589-1606 \mathrm{~cm}^{-1}$ in the metal complexes indicating the participation of carboxylic oxygen atom in complex formation[17,18].Moreover, in all the complexes, $v_{\text {asy }}(\mathrm{OCO})$ and $v_{\text {sym }}(\mathrm{OCO})$ were observed at around 1589-1606 and $1471-1487 \mathrm{~cm}^{-1}$, and the difference were found to be less than $200 \mathrm{~cm}^{-1}\left(\Delta=102-129 \mathrm{~cm}^{-1}\right)$ indicating the carboxylate oxygen coordinate to the metal atom in bidentated fashion[19].The $\mathrm{O}-\mathrm{H}$ absorption bands in free ligands remains almost unchanged in the complexes indicating the phenolic oxygen do not take part in the complex formation [1].Bands at 1167 and 1383 $\mathrm{cm}^{-1}$ in $\mathrm{L}_{2}$ are attributed to symmetric and anti-symmetric stretching vibrations of the sulfone group $v(\mathrm{O}=\mathrm{S}=\mathrm{O})$ in the free ligand $\left(\mathrm{L}_{2}\right)[20,21,22]$; these bands remains unchanged in the complexes suggesting that sulfonamide oxygen is not involved in coordination. In the metal complexes, there are new medium to weak bands appearing at frequency between 571 and $578 \mathrm{~cm}^{-1}$ which may be assigned to M-O bond [13].

\section{${ }^{1} \mathrm{H}-\mathrm{NMR}$ spectra}

The ${ }^{1} \mathrm{H}-\mathrm{NMR}$ spectra of the azo carboxylic acid ligands $\mathrm{L}_{1}$ and $\mathrm{L}_{2}$ were recorded in DMSO- $d_{6}$. The NMR data are presented in experimental section. In ${ }^{1} \mathrm{H}$-NMR spectrum of the ligand $\mathrm{L}_{2}$, the multiplet peak around 6.9-8.48 are assigned to the aromatic protons. The singlet peak at around $\delta 7.51 \mathrm{ppm}$ in $\mathrm{L}_{2}$ may be assigned to two protons of $\mathrm{SO}_{2} \mathrm{NH}_{2}$ while multiplet peaks appeared at around $\delta 7.16-8.37 \mathrm{ppm}$ are due to aromatic protons.Signals for the phenol and carboxylic acid were exchanged due to presence of water in the solvent [11].

\subsection{Molarconductance}

The molar Conductance of the synthesized complexes were measured using $10^{-3} \mathrm{M}$ DMF solvent at room temperature and given in Table 2 . The Conductivity values of the complexes (1-4) are in the range of 12$17 \Omega^{-1} \mathrm{~cm}^{-2} \mathrm{~mol}^{-1}$.These values are too low to account for any dissociation of the complexes in DMF and the obtained values were taken as a good evidence for the existence of a non-electrolytic in nature of the complexes. The complexes 5-6 exhibited conductivity values in the range of $68.4-74.8 \Omega^{-1} \mathrm{~cm}^{-2} \mathrm{~mol}^{-1}$ indicating 1:1 electrolytic nature in these complexes [23].

\subsection{Antimicrobial activity}

Antibacterial and antifungal activity were performed using disc diffusion method at 2.5 and $5 \mathrm{mg} / \mathrm{ml}$ in DMSO. Ciprofloxacin and Amphotericin-B were used as standard reference for antibacterial and antifungal activities, respectively. P. Mirabilis, K. Pneumonia, E. Coli, S.Paratyphi and P.Aeruginosa were used for antibacterial study while A.Flavus, A. Fumigatus, A. Niger, C. Albicans and C. Krusei were employed for their antfungal study. Agar diffusion technique was used for the test. Zone of inhibition (mm) are presented in Table 4 and 5. The result of fungicidal screening (Table-4) show that complex $\mathbf{5}$ is active against C.Albicans and $C$. Krusei whereas other complexes show resistance to all the fungal stain. $\mathrm{Cu}(\mathrm{II})$ complexes are effective on bacterial stain while they are resistant to all the fungi. A general observation is that $\mathrm{Ni}(\mathrm{II})$ complexes are more effective than the $\mathrm{Cu}(\mathrm{II})$ complexes. The greater antimicrobial activity of $\mathrm{Ni}(\mathrm{II})$ complexes may be explained on the basis of particle size and the size of metal ion [24] and on chelation theory [25-28].It has been suggested that the mode of action of the complexes may probably involve the formation of $\mathrm{H}$ - bond through phenolic $\mathrm{OH}$ group of the compounds with the active centre of the cell constituents thereby resulting interference with normal cell process $[1,26]$.The minimum inhibition concentration for all the synthesized complexes were determined against all the tested fungi and bacteria and the values are given in Table 6.Theantimicrobial activity of synthesized complexes are comparable with those of the reported compounds $[1,16]$. However these complexes are less effective than the standard drugs.

\section{Conclusion}

Some $\mathrm{Cu}(\mathrm{II})$ and $\mathrm{Ni}(\mathrm{II})$ complexes of azo-carboxylate were synthesised and characterised by conductivity, electronic and IR spectroscopy. The IR studyof metal complexes show that the carboxylate ligands coordinated in bidentate fashion in all the complexes andthe hydroxyl group of the ligand do not take part in bond formation in the complexes. From UV-Vis. spectra of the complexes, both $\mathrm{Cu}$ (II) and $\mathrm{Ni}(\mathrm{II})$ complexes may be proposed to have square planar geometry. Conductivity study shows that $\mathrm{Cu}(\mathrm{II})$ complexes are nonelectrolyte whereas $\mathrm{Ni}$ (II) complexes are electrolytic in nature [23].The synthesised complexes were tested for their in vitro antifungal and antibacterial activities and compared with the standard drugs, Amphotericin-B and Ciprofloxacin. $\mathrm{Cu}(\mathrm{II})$ complexes were found to be inactive against the tested fungal species but they show moderate activity against the tested bacterial species. In general $\mathrm{Ni}$ (II) complexes are more effective than the $\mathrm{Cu}$ (II) complexes against the microbes. Among the tested complexes, $\left[\mathrm{Ni}(\mathrm{II})\left(\mathrm{L}_{1}\right)_{2}\right] \cdot \mathrm{SO}_{4}$ is effective in both bacterial and fungal stain whereas $\left[\mathrm{Ni}(\mathrm{II})\left(\mathrm{L}_{2}\right)_{2}\right] . \mathrm{SO}_{4}$ is effective only in bacterial stain but resistant to fungal stain.However, the complexes are less effective than the standard drugs. 


\section{Acknowledgement}

We would like to thank Department of Science and Technology, Government of India, New Delhi for the financial support (grant no. SERC /FT/CS-051/2008).

\section{References}

[1] C.D. Sheela, C.Anitha, P.Tharmaraj and D.Kodimunthri, J. Coord.Chem., 63,2010, 884

[2] K.Singh,M.S. Barwa, P. Tyagi,Eur.J.Med.Chem., 42,2007, 394.

[3] P.G.Cozzi, Chem.Soc.Rev., 33,2004, 410.

[4] S.Chandra,J.Sangeetika, Journal of Indian Chemical Society, 81,2004, 203.

[5] M.B.Ferrari, S.Capacchi, G.Pelosi, G.Reffo, P.Tarasconi, R. Albertini, S.Pinelli, P.Lunghi,Inorg. Chim.Acta, 286, $1999,134$.

[6] E.Canpolat, M.Kaya, J.Coord.Chem., 57,2004, 1217.

[7] M.Yildiz, B.Dulger,S.Y.Koyuncu, B.M.Yapici, Journal of Indian Chemical Society, 81, 2004,7

[8] M.B.Ferrari, S.Capacchi, G.Pelosi, G.Reffo, P.Tarasconi, R.Albertini, S.Pinelli, P.Lunghi. Inorg.Chim.Acta.,286, 1999, 134

[9] E. Canpolat,B.Dulger,S.Y.Koyuncu, B.M. Yapici,Journal of Indian Chemical Society,81,2004, 7.

[10] C. H. Zahid, M.Arif, M. A. Akhtar, and Claudiu, T. Supuran, Bio.Inorg. Chem.andAppl.,2006, $2006,1$.

[11] T.S. BasuBaul, S.Dhar, S.M.Pyke,E.R.T.Tiekink, E.Rivarola, R.Butcher, F.E.Smith, J.Organomet.Chem., 633,2001, 7.

[12] D.S.Reeves, I.Phillips, J.D.Williams, Laboratory Methods in Antimicrobial Chemotherapy. Longman Group Ltd, Edinburgh, 1979, pp. 20.

[13] D.M.Boghaei, M.Lashanizadegan, J. Sci. I.R. Iran, 11(4), 2000, 301

[14] X.R.Bu,C.R.Jackson,D.V.Derveer,X.Z.You,Q.J.Meng,R.X.Wang, Polyhedron.,16,1997, 2991.

[15] G.A.Kolawole,A.A. Osowole, J.Coord. Chem..,62, 2009, 1437.

[16] A.A.Nejo,G.A.Kolawole, M.C.Dumbele, A.R. Opoku, J. Cord. Chem.,63,2010, 4367.

[17] J.Vanco, J.Marek, Z.Travnicek, E. Racanska,J. Muselik, O.Svajlenova,J.Inorg.Bio.Chem.,102, 2008,595.

[18] K.Nakamoto (Eds.), Infrared and Raman Spectra of Inorganic and Coordination Compounds, fifth ed., Wiley, New York, 1997.

[19] Aziz-ur-Rehman et al. Inorg.Chim.Acta,370,2011, 27.

[20] C.M.Sharaby, Spectrochim. Acta, 66 A, 2007, 1271.

[21] R.E. Mukalyk, L.G.Chaltes, Can.J. Chem., 45, 1968, 1411.

[22] S. Joshi, N. Khosla, D. Khare, P. Tiwan, Acta Pharm.,52, 2002, 197.

[23] W.J.Geary,Coord. Chem.Rev., 7(1),1971, 81-122.

[24] R.M. Issa, S.A. Azim,A.M.Khedr, D.F. Draz,J.Coord. Chem.,62, 2009,1859.

[25] N. Dharmaraj, P. Viswanathamurthi, K. Natarajan, Transition Met.Chem.,26, 2001, 105.

[26] L. Mishra, U.K. Siyh, Indian Journal of Chemistry,32A, 1993, 446.

[27] P.B. Chakrawarthi,Journal of Indian Chemical Society, 78, 2001, 273.

[28] R.K. Ray, G.R. Kauffman, Inorg. Chim.Acta,173,2001,207. 
<smiles>[X]c1ccc(N)cc1</smiles>

$10 \% \mathrm{NaOH}$

$0-2^{\circ} \mathrm{C}$

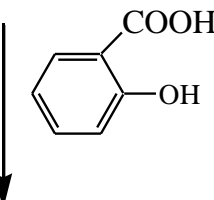

Where $\quad \mathrm{L}_{1}=\mathrm{X}=-\mathrm{CH}_{3}$,<smiles>[X]c1ccc(/N=N/c2ccc(O)c(C(=O)O)c2)cc1</smiles>

$\mathrm{L}_{1} / \mathrm{L}_{2}$<smiles>[X]c1ccc(/N=N/c2ccc(O)c(C(=O)O)c2)cc1</smiles>

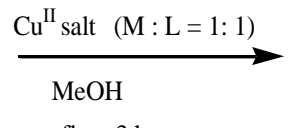<smiles>[X]c1ccc(N=Nc2ccc(O)c(C(=O)O[Al]34CC(C)(O3)O4)c2)cc1</smiles>

Square planar $\mathrm{Cu}(\mathrm{II})$ complex

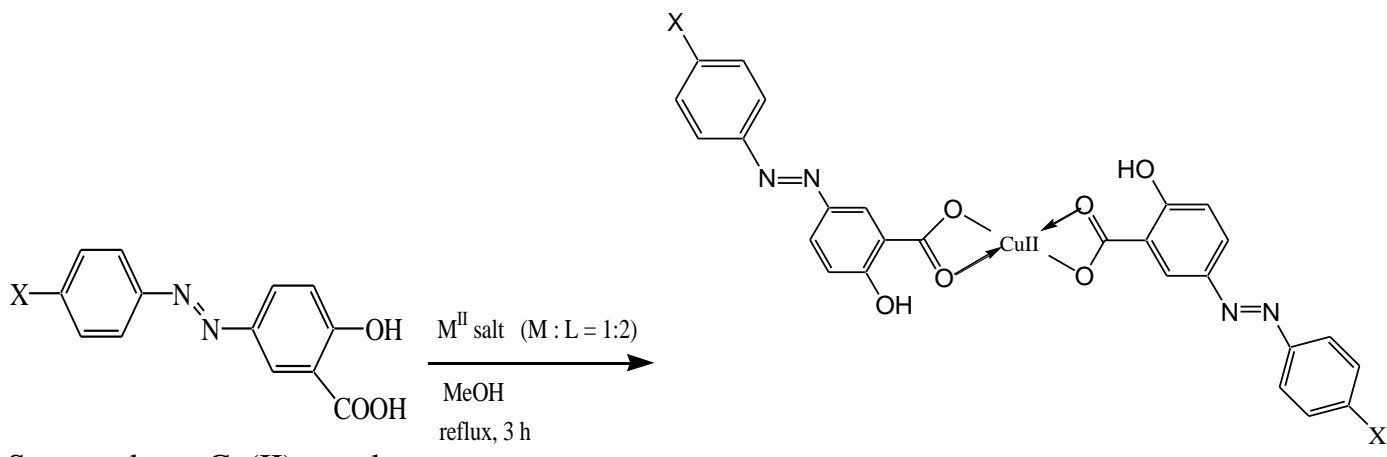

Square planar $\mathrm{Cu}(\mathrm{II})$ complex

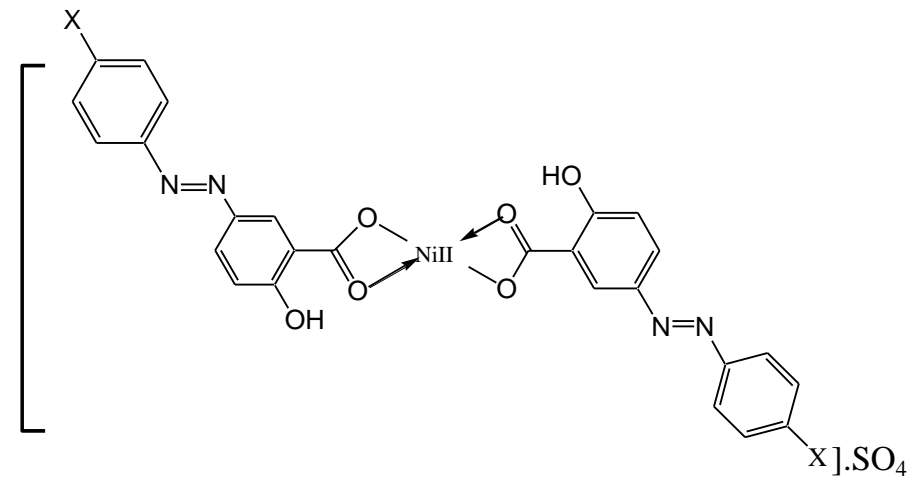

Square planar Ni(II)complex

Scheme 1:Synthesis of ligands and their corresponding $\mathrm{Cu}(\mathrm{II})$ and $\mathrm{Ni}(\mathrm{II})$ complexes (Where $\mathrm{M}^{\mathrm{II}}$ salt $=\mathrm{Cu}(\mathrm{II}) \& \mathrm{Ni}(\mathrm{II})$ salt $)$. 
Synthesis, characterization and in vitro Antimicrobial activity of $\mathrm{Cu}(\mathrm{II})$ and $\mathrm{Ni}(\mathrm{II})$ complexes of Azo

Table-1 :Physical characteristics of ligands and metal(II) complexes

\begin{tabular}{|c|c|c|c|c|c|c|c|}
\hline \multirow[t]{2}{*}{ Compounds } & \multirow{2}{*}{$\begin{array}{c}\text { Formula } \\
\text { weight }\end{array}$} & \multirow[t]{2}{*}{ Colour } & \multirow[t]{2}{*}{ Solubility } & \multicolumn{3}{|c|}{ Analysis found (Calculated) } & \multirow[t]{2}{*}{$\mathrm{M}: \mathrm{L}$} \\
\hline & & & & $\mathrm{C} \%$ & $\mathrm{H} \%$ & $\mathrm{~N} \%$ & \\
\hline Ligand $\left(\mathrm{L}_{1}\right)$ & 256 & Brown & $\mathrm{MeOH}$ & $65.49(65.62)$ & $4.59(4.68)$ & $10.87(10.93)$ & - \\
\hline Ligand $\left(\mathrm{L}_{2}\right)$ & 321 & Orange & $\mathrm{MeOH}$ & $48.51(48.59)$ & $3.36(3.43)$ & $12.99(13.08)$ & - \\
\hline$\left[\mathrm{Cu}(\mathrm{II}) \mathrm{L}_{1}(\mathrm{ac})\right]$ & 395.5 & Dark brown & DMSO & $48.17(48.54)$ & $3.97(4.04)$ & $6.89(7.07)$ & $1: 1$ \\
\hline$\left[\mathrm{Cu}(\mathrm{II})\left(\mathrm{L}_{1}\right)_{2}\right]$ & 573.5 & Dark brown & DMSO & $58.31(58.59)$ & $3.71(3.83)$ & $9.64(9.76)$ & $1: 2$ \\
\hline$\left[\mathrm{Cu}(\mathrm{II}) \mathrm{L}_{2}(\mathrm{ac})\right]$ & 442.5 & Dark brown & DMSO & $40.56(40.67)$ & $2.82(2.94)$ & $9.33(9.49)$ & $1: 1$ \\
\hline$\left[\mathrm{Cu}(\mathrm{II})\left(\mathrm{L}_{2}\right)_{2}\right]$ & 701.5 & Dark brown & DMSO & $44.29(44.47)$ & $2.49(2.56)$ & $11.86(11.97)$ & $1: 2$ \\
\hline$\left[\mathrm{Ni}(\mathrm{II})\left(\mathrm{L}_{1}\right)_{2}\right] \cdot \mathrm{SO}_{4}(\mathbf{5})$ & 586 & Yellow & DMSO & $57.24(57.33)$ & $3.98(4.09)$ & $9.38(9.55)$ & $1: 2$ \\
\hline$\left[\mathrm{Ni}(\mathrm{II})\left(\mathrm{L}_{2}\right)_{2}\right] \cdot \mathrm{SO}_{4}(\mathbf{6})$ & 732 & Yellow & DMSO & $42.48(42.62)$ & $2.89(3.00)$ & $11.32(11.47)$ & $1: 2$ \\
\hline
\end{tabular}

Table -2: Electronic spectral and conductance data of the metal (II) complexes

\begin{tabular}{|l|c|c|c|c|}
\hline \multicolumn{1}{|c|}{ Compounds } & $\begin{array}{c}\text { d-d transitions/cm } \\
1\end{array}$ & C.T. & $\pi \rightarrow \pi^{*}$ & $\begin{array}{c}\text { Observed molar } \\
\text { conductance }\end{array}$ \\
\hline $\mathbf{( 1 )}\left[\mathrm{Cu}(\mathrm{II}) \mathrm{L}_{1}(\mathrm{ac})\right]$ & $25253(396 \mathrm{~nm})$ & $32051(312 \mathrm{~nm})$ & $40650(246 \mathrm{~nm})$ & $13.2 \Omega^{-1} \mathrm{~cm}^{-} \mathrm{mol}^{-1}$ \\
\hline $\mathbf{( 2 )}\left[\mathrm{Cu}(\mathrm{II})\left(\mathrm{L}_{1}\right)_{2}\right]$ & $25381(396 \mathrm{~nm})$ & $32787(305 \mathrm{~nm})$ & $40816(245 \mathrm{~nm})$ & $12.3 \Omega^{-1} \mathrm{~cm}^{-} \mathrm{mol}^{-1}$ \\
\hline $\mathbf{( 3 )}\left[\mathrm{Cu}(\mathrm{II}) \mathrm{L}_{2}(\mathrm{ac})\right]$ & $24038(416 \mathrm{~nm})$ & $31847(314 \mathrm{~nm})$ & $40323(248 \mathrm{~nm})$ & $12.7 \Omega^{-1} \mathrm{~cm}^{-} \mathrm{mol}^{-1}$ \\
\hline $\mathbf{( 4 )}\left[\mathrm{Cu}(\mathrm{II})\left(\mathrm{L}_{2}\right)_{2}\right]$ & $24155(414 \mathrm{~nm})$ & $31646(316 \mathrm{~nm})$ & $40486(247 \mathrm{~nm})$ & $16.3 \Omega^{-1} \mathrm{~cm}^{-} \mathrm{mol}^{-1}$ \\
\hline $\mathbf{( 5 )}\left[\mathrm{Ni}(\mathrm{II})\left(\mathrm{L}_{1}\right)_{2}\right] . \mathrm{SO}_{4}$ & $25126(398 \mathrm{~nm})$ & $32051(312 \mathrm{~nm})$ & $40816(245 \mathrm{~nm})$ & $68.4 \Omega^{-1} \mathrm{~cm}^{-} \mathrm{mol}^{-1}$ \\
\hline $\mathbf{( 6 )}\left[\mathrm{Ni}(\mathrm{II})\left(\mathrm{L}_{2}\right)_{2}\right] \cdot \mathrm{SO}_{4}$ & $25189(397 \mathrm{~nm})$ & $32051(312 \mathrm{~nm})$ & $40984(244 \mathrm{~nm})$ & $74.8 \Omega^{-1} \mathrm{~cm}^{-} \mathrm{mol}^{-1}$ \\
\hline
\end{tabular}

Table- 3:Some IR frequencies (in $\mathrm{cm}^{-1}$ ) of $\mathrm{Cu}(\mathrm{II}) \& \mathrm{Ni}(\mathrm{II})$ complexes

\begin{tabular}{|c|c|c|c|c|c|c|c|}
\hline Complex & $v_{\text {asy }}(\mathrm{OCO})$ & $v_{\text {sym }}(\mathrm{OCO})$ & $v(\mathrm{OH})$ & $v(\mathrm{~N}=\mathrm{N})$ & $v(\mathrm{C}-\mathrm{O})$ & $v(\mathrm{~S}=\mathrm{O})$ & $v(\mathrm{M}-\mathrm{O})$ \\
\hline Ligand $\left(\mathrm{L}_{1}\right)$ & 1655 & 1591 & 3347 & 1578 & 1333 & - & - \\
\hline Ligand $\left(\mathrm{L}_{2}\right)$ & 1665 & 1591 & 3266 & 1578 & 1337 & 1385 & - \\
\hline$\left[\mathrm{Cu}(\mathrm{II}) \mathrm{L}_{1}(\mathrm{ac})\right]$ & 1604 & 1479 & 3323 & 1558 & 1338 & - & 571 \\
\hline$\left[\mathrm{Cu}(\mathrm{II})\left(\mathrm{L}_{1}\right)_{2}\right]$ & 1604 & 1475 & 3311 & 1558 & 1336 & - & 571 \\
\hline$\left[\mathrm{Cu}(\mathrm{II}) \mathrm{L}_{2}(\mathrm{ac})\right] \quad$ (3) & 1606 & 1479 & 3259 & 1560 & 1327 & 1396 & 574 \\
\hline$\left[\mathrm{Cu}(\mathrm{II})\left(\mathrm{L}_{2}\right)_{2}\right]$ & 1606 & 1477 & 3259 & 1558 & 1325 & 1386 & 574 \\
\hline$\left[\mathrm{Ni}(\mathrm{II})\left(\mathrm{L}_{1}\right)_{2}\right] \cdot \mathrm{SO}_{4}(\mathbf{5})$ & 1600 & 1471 & 3259 & 1562 & 1381 & - & 578 \\
\hline$\left[\mathrm{Ni}(\mathrm{II})\left(\mathrm{L}_{2}\right)_{2}\right] \cdot \mathrm{SO}_{4} \quad(\mathbf{6})$ & 1589 & 1487 & 3308 & 1487 & 1305 & 1394 & 574 \\
\hline
\end{tabular}


Table- 4:Antifungal activity (zone of inhibition)

\begin{tabular}{|c|c|c|c|c|c|c|c|c|c|c|}
\hline \multirow{3}{*}{ Compounds } & \multicolumn{10}{|c|}{ Zone of inhibitions $(\mathrm{mm})(\mathrm{mg} / \mathrm{ml})$} \\
\hline & \multicolumn{2}{|c|}{ A. Flavus } & \multicolumn{2}{|c|}{ A. Fumigatus } & \multicolumn{2}{|c|}{ A. Niger } & \multicolumn{2}{|c|}{ C. Albicans } & \multicolumn{2}{|c|}{ C. Krusei } \\
\hline & 5 & 2.5 & 5 & 2.5 & 5 & 2.5 & 5 & 2.5 & 5 & 2.5 \\
\hline (1) $\left[\mathrm{Cu}(\mathrm{II}) \mathrm{L}_{1}(\mathrm{ac})\right]$ & - & - & - & - & - & - & - & - & - & - \\
\hline (2) $\left[\mathrm{Cu}(\mathrm{III})\left(\mathrm{L}_{1}\right)_{2}\right]$ & - & - & - & - & - & - & - & - & - & - \\
\hline (4) $\left[\mathrm{Cu}(\mathrm{II})\left(\mathrm{L}_{2}\right)_{2}\right]$ & - & - & - & - & - & - & - & - & - & - \\
\hline (5) $\left[\mathrm{Ni}(\mathrm{II})\left(\mathrm{L}_{1}\right)_{2}\right] \cdot \mathrm{SO}_{4}$ & - & - & - & - & - & - & 12 & 10 & 12 & 8 \\
\hline (6) $\left[\mathrm{Ni}(\mathrm{II})\left(\mathrm{L}_{2}\right)_{2}\right] \cdot \mathrm{SO}_{4}$ & - & - & - & - & - & - & - & - & - & - \\
\hline DMSO & - & - & - & - & - & - & - & - & - & - \\
\hline $\mathrm{AM}(16 \mu \mathrm{g} / \mathrm{ml})$ & \multicolumn{2}{|c|}{32} & \multicolumn{2}{|c|}{34} & \multicolumn{2}{|c|}{38} & \multicolumn{2}{|c|}{38} & \multicolumn{2}{|c|}{40} \\
\hline
\end{tabular}

Table-5:Antibacterial activity (zone of inhibition)

\begin{tabular}{|c|c|c|c|c|c|c|c|c|c|c|}
\hline \multirow{3}{*}{ Compounds } & \multicolumn{10}{|c|}{ Zone of inhibitions $(\mathrm{mm})(\mathrm{mg} / \mathrm{ml})$} \\
\hline & \multicolumn{2}{|c|}{ P. Mirabilis } & \multicolumn{2}{|c|}{ K. Pneumoniae } & \multicolumn{2}{|c|}{ E.Coli } & \multicolumn{2}{|c|}{ S. Paratyphi } & \multicolumn{2}{|c|}{ P. Aeruginosa } \\
\hline & 5 & 2.5 & 5 & 2.5 & 5 & 2.5 & 5 & 2.5 & 5 & 2.5 \\
\hline (1) $\left[\mathrm{Cu}(\mathrm{II}) \mathrm{L}_{1}(\mathrm{ac})\right]$ & - & - & 14 & 12 & - & - & - & - & 10 & - \\
\hline (2) $\left[\mathrm{Cu}(\mathrm{II})\left(\mathrm{L}_{1}\right)_{2}\right]$ & - & - & - & - & 12 & 8 & - & - & - & - \\
\hline (4) $\left[\mathrm{Cu}(\mathrm{III})\left(\mathrm{L}_{2}\right)_{2}\right]$ & - & - & - & - & - & - & - & - & 12 & 8 \\
\hline (5) $\left[\mathrm{Ni}(\mathrm{II})\left(\mathrm{L}_{1}\right)_{2}\right] . \mathrm{SO}_{4}$ & 16 & 12 & 12 & 10 & - & - & - & - & 14 & 12 \\
\hline (6) $\left[\mathrm{Ni}(\mathrm{II})\left(\mathrm{L}_{2}\right)_{2}\right] . \mathrm{SO}_{4}$ & - & - & - & - & 10 & - & - & - & - & - \\
\hline DMSO & - & - & - & - & - & - & - & - & - & - \\
\hline CIP $(16 \mu \mathrm{g} / \mathrm{ml})$ & \multicolumn{2}{|c|}{32} & \multicolumn{2}{|c|}{34} & \multicolumn{2}{|c|}{36} & \multicolumn{2}{|c|}{36} & \multicolumn{2}{|c|}{34} \\
\hline
\end{tabular}

Table- 6:Minimuminhibition concentration for tested Fungi (Concentration in $\mu \mathrm{g} \mathrm{mL}^{-1}$ )

\begin{tabular}{|c|c|c|c|c|c|}
\hline Compounds & A. Flavus & A. Fumigatus & A. Niger & C. Albicans & C. Krusei \\
\hline (1) $\left[\mathrm{Cu}(\mathrm{II}) \mathrm{L}_{1}(\mathrm{ac})\right]$ & $>5000$ & $>5000$ & $>5000$ & $>5000$ & $>5000$ \\
\hline (2) $\left[\mathrm{Cu}(\mathrm{II})\left(\mathrm{L}_{1}\right)_{2}\right]$ & $>5000$ & $>5000$ & $>5000$ & $>5000$ & $>5000$ \\
\hline (4) $\left[\mathrm{Cu}(\mathrm{II})\left(\mathrm{L}_{2}\right)_{2}\right]$ & $>5000$ & $>5000$ & $>5000$ & $>5000$ & $>5000$ \\
\hline (5) $\left[\mathrm{Ni}(\mathrm{II})\left(\mathrm{L}_{1}\right)_{2}\right] \cdot \mathrm{SO}_{4}$ & $>5000$ & $>5000$ & $>5000$ & 156.25 & 312.5 \\
\hline (6) $\left[\mathrm{Ni}(\mathrm{II})\left(\mathrm{L}_{2}\right)_{2}\right] \cdot \mathrm{SO}_{4}$ & $>5000$ & $>5000$ & $>5000$ & $>5000$ & $>5000$ \\
\hline $\mathrm{AM}(16 \mu \mathrm{g} / \mathrm{ml})$ & 0.5 & 1.0 & 0.5 & $<0.5$ & $>0.5$ \\
\hline \multirow[t]{2}{*}{ Compounds } & \multicolumn{5}{|c|}{ MIC for tested bacteria (Concentration in $\mu \mathrm{g} \mathrm{mL}^{-1}$ ) } \\
\hline & P. Mirabilis & K. Pneumoniae & E.Coli & S. Paratyphi & P. Aeruginosa \\
\hline (1) $\left[\mathrm{Cu}(\mathrm{II}) \mathrm{L}_{1}(\mathrm{ac})\right]$ & $>5000$ & 78.12 & $>5000$ & $>5000$ & 312.5 \\
\hline (2) $\left[\mathrm{Cu}(\mathrm{II})\left(\mathrm{L}_{1}\right)_{2}\right]$ & $>5000$ & $>5000$ & $<1250$ & $>5000$ & $>5000$ \\
\hline (4) $\left[\mathrm{Cu}(\mathrm{II})\left(\mathrm{L}_{2}\right)_{2}\right]$ & $>5000$ & $>5000$ & $>5000$ & $>5000$ & 312.5 \\
\hline$(\mathbf{5})\left[\mathrm{Ni}(\mathrm{II})\left(\mathrm{L}_{1}\right)_{2}\right] \cdot \mathrm{SO}_{4}$ & 39.06 & $<156.25$ & $>5000$ & $>5000$ & $<39.06$ \\
\hline (6) $\left[\mathrm{Ni}(\mathrm{II})\left(\mathrm{L}_{2}\right)_{2}\right] \cdot \mathrm{SO}_{4}$ & $>5000$ & $>5000$ & $<1250$ & $>5000$ & $>5000$ \\
\hline CIP $(16 \mu \mathrm{g} / \mathrm{ml})$ & 1.0 & 0.5 & 0.5 & 0.5 & 0.5 \\
\hline
\end{tabular}




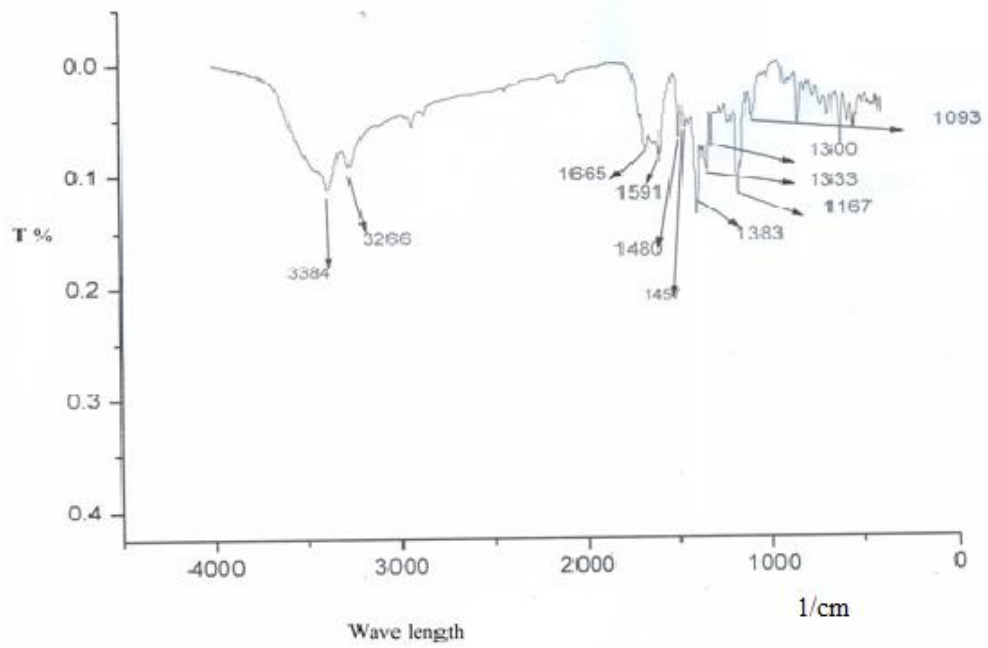

Fig-2: IR spectrum of $\mathrm{L}_{2}$

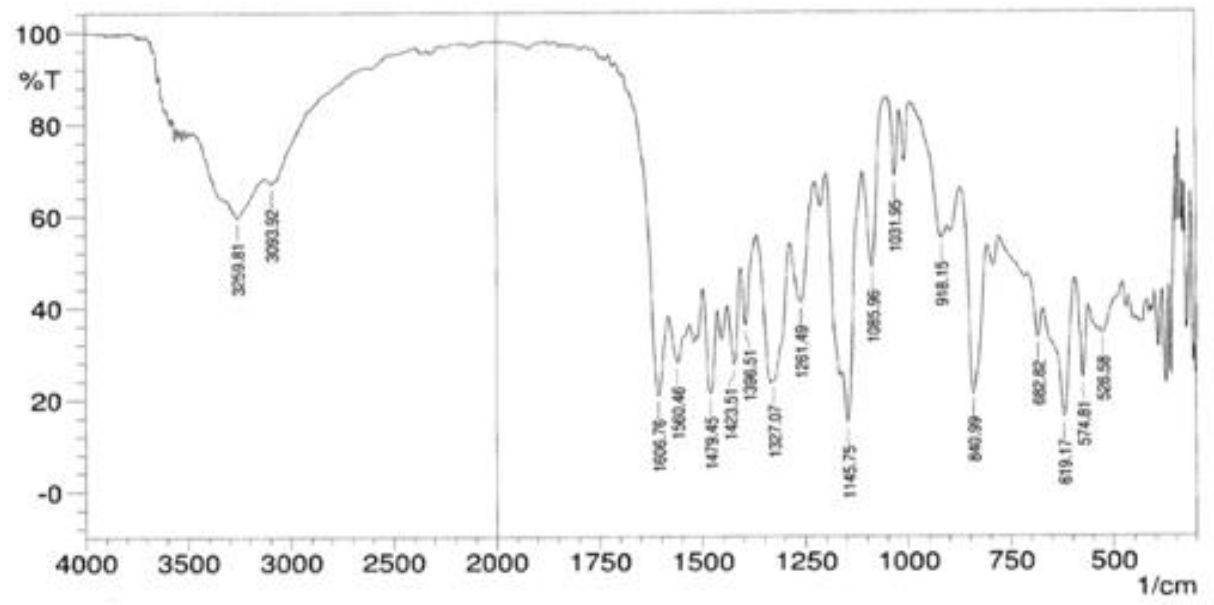

Fig-3: IR spectrum of $\left[\mathrm{Cu}(\mathrm{II})\left(\mathrm{L}_{2}\right) \mathrm{ac}\right]$

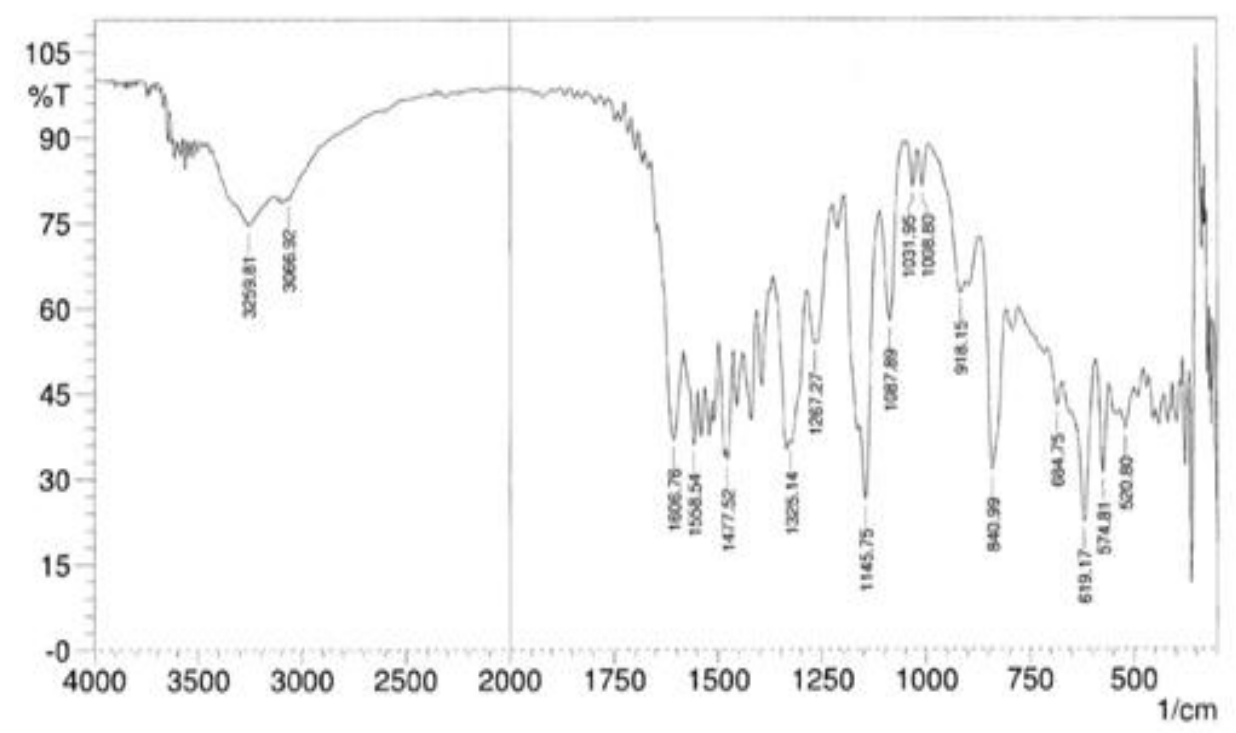

Fig- 4: IR spectrum of $\left[\mathrm{Cu}(\mathrm{II})\left(\mathrm{L}_{2}\right)_{2}\right]$ 


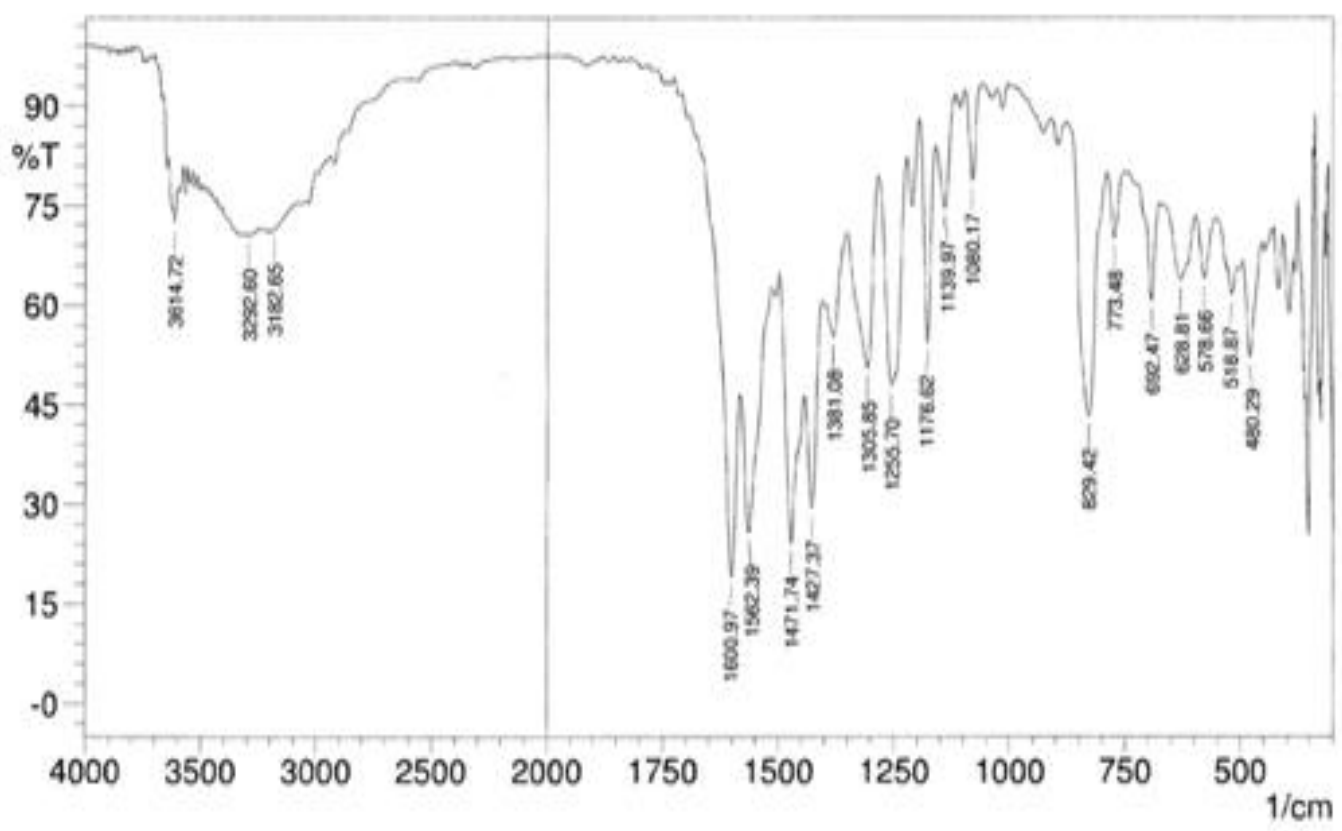

Fig-5: IR spectrum of $\left[\mathrm{Ni}(\mathrm{II})\left(\mathrm{L}_{1}\right)_{2}\right] \cdot \mathrm{SO}_{4}$ 